\title{
Bovine Viral Diarrhea Virus in Cattle From Mexico: Current Status
}

\author{
Ninnet Gomez-Romero ${ }^{1 *}$, Julia F. Ridpath ${ }^{2}$, Francisco Javier Basurto-Alcantara ${ }^{1}$ and \\ Antonio Verdugo-Rodriguez ${ }^{3}$
}

'Vaccinology Laboratory, Department of Microbiology and Immunology, Facultad de Medicina Veterinaria y Zootecnia-Universidad Nacional Autónoma de México, Mexico City, Mexico, ${ }^{2}$ Ridpath Consulting, LLC and Ruminant Diseases and Immunology Research Unit, National Animal Disease Center, Ames, IA, United States, ${ }^{3}$ Molecular Microbiology Laboratory, Department of Microbiology and Immunology, Facultad de Medicina Veterinaria y Zootecnia-Universidad Nacional Autónoma de México, Mexico City, Mexico

OPEN ACCESS

Edited by:

Alejandra Victoria Capozzo, Consejo Nacional de Investigaciones Científicas y Técnicas (CONICET), Argentina

Reviewed by: Gabriella Elia,

University of Bari Aldo Moro, Italy Juliana Felipetto Cargnelutti,

Federal University of Santa Maria, Brazil

*Correspondence: Ninnet Gomez-Romero ninnet.gomez@comunidad.unam.mx; ninna_gr@hotmail.com

Specialty section: This article was submitted to Veterinary Epidemiology and Economics,

a section of the journal Frontiers in Veterinary Science

Received: 27 February 2021 Accepted: 15 July 2021 Published: 13 August 2021

Citation:

Gomez-Romero N, Ridpath JF Basurto-Alcantara FJ and Verdugo-Rodriguez A (2021) Bovine Viral Diarrhea Virus in Cattle From Mexico: Current Status.

Front. Vet. Sci. 8:673577.

doi: 10.3389/fvets.2021.673577
Bovine viral diarrhea (BVD) is an infectious disease, globally-distributed, caused by bovine Pestiviruses, endemic of cattle and other ruminant populations. BVD leads to significant economic losses to the cattle industry due to the wide range of clinical manifestations, including respiratory and gastrointestinal diseases and reproductive disorders. Within the Pestivirus genus of the family Flaviviridae three viral species are associated with BVD; Pestivirus A (Bovine viral diarrhea virus 1, BVDV-1), Pestivirus B (Bovine viral diarrhea virus 2, BVDV-2), and Pestivirus H (HoBi-like pestivirus, atypical ruminant pestivirus). These species are subdivided into subgenotypes based on phylogenetic analysis. The extensive genetic diversity of BVDV has been reported for several countries, where the incidence and genetic variation are more developed in Europe than in the Americas. The first report of BVDV in Mexico was in 1975; this study revealed seropositivity of $75 \%$ in cows with a clinical history of infertility, abortions, and respiratory disease. Other studies have demonstrated the presence of antibodies against BVDV with a seroprevalence ranging from 7.4 to 100\%. Recently, endemic BVDV strains affecting cattle populations started to be analyzed, providing evidence of the BVDV diversity in several states of the country, revealing that at least four subgenotypes (BVDV-1a, 1b, 1c, and 2a) are circulating in animal populations in Mexico. Little information regarding BVD epidemiological current status in Mexico is available. This review summarizes available information regarding the prevalence and genetic diversity viruses associated with BVD in cattle from Mexico.

\section{Keywords: bovine viral diarrhea virus, pestivirus, genotypes, subgenotypes, Mexico}

\section{INTRODUCTION}

Bovine viral diarrhea (BVD) affects cattle and ruminants worldwide, leading to significant economic losses (1). The viruses that cause BVD are currently divided into three species within the Pestivirus genus; Pestivirus A (Bovine viral diarrhea virus 1, BVDV-1), Pestivirus B (Bovine viral diarrhea 2, BVDV-2), and Pestivirus $H$ (HoBi-like pestivirus, atypical ruminant pestivirus) (2). Phylogenetic analysis has led to the segregation of BVDV-1 into at least 21 subgenotypes (BVDV 1a- $1 \mathrm{u}$ ) and BVDV-2 (BVDV 2a-2d) and HoBi-like viruses into four subgenotypes (a-d) each (3). Analysis of the entire genome is still the most reliable criteria when BVDV genetic characterization is performed; although, sequences of the 5'UTR (untranslated region), E2 glycoprotein, and 3'UTR are used to assign species and subgenotypes, obtaining similar results (4-6). Additionally, these viruses may exist as two different biotypes, cytopathic (CP) and non-cytopathic (NCP), according 
to their activity in cell culture. Cytopathology in vitro is not related to pathogenicity in vivo. NCP biotype predominate in nature, while $\mathrm{CP}$ strains are rare and mostly associated with outbreaks of a rare fatal form of BVD named mucosal disease (7).

The term BVD includes a complex range of clinical presentations. In general, BVD is characterized by clinical manifestations including respiratory, gastrointestinal disorders, and reproductive failures such as congenital malformations, abortions, mummification, stillbirth, and as a result of transplacental infection, the birth of immunotolerant persistent infected animals (PI). These PI animals shed virus throughout their lifetime, play an essential role in BVD pathogenesis and represents one of the main sources of viral infection (8). Infection with viruses associated with BVD is suggested as an initiating event for the development of bovine respiratory disease complex (BRDC) (9) and also leads to an increased susceptibility to other diseases due to either immunosuppression or synergism with other viral and bacterial pathogens $(10,11)$. Infection in pregnant sheep, goat, pigs, and wild ruminants results in a clinical presentation similar to that seen in cattle and contact among these animal species facilitates viral transfer among domestic and non-domestic ruminants (12-15).

\section{DISTRIBUTION OF BVDV SUBGENOTYPES}

Phylogenetic approaches have been used to determine the prevalence of BVD associated species and subgenotypes within those species in different geographic locations. These studies revealed that BVDV-1 has a broader distribution than BVDV2 and HoBi-like viruses. BVDV-1 displayed a higher genetic diversity suggested by the number of subgenotypes reported overall; the BVDV-1b has been the predominant subgenotype worldwide, followed by BVDV-1a and 1c. Regarding BVDV-2, subgenotype $2 \mathrm{a}$ is the most prevalent globally, whereas BVDV$2 \mathrm{~b}, 2 \mathrm{c}$, and $2 \mathrm{~d}$ have been only detected in European and Asian countries (3). In addition, to date, HoBi-like viruses have only been detected in South America, Europe, and Asia but not in North America (16-18). Studies based on viruses found in Mexican cattle revealed the presence of at least four BVDV subgenotypes (BVDV 1a, 1b,1c, and BVDV 2a) with no evidence of HoBi-like viruses detected (19). Seroprevalence studies indicate an BVDV exposure since 1975 to date (20). No PI prevalence studies have been performed to date.

Characterization of BVDV subgenotypes continues to be a relevant matter of discussion due to the implications that variations have for detection, diagnosis, and vaccine efficacy. Variations among subgenotypes have demonstrated a direct impact in BVDV detection and vaccination, the latter, reported by previous studies where protection conferred against vaccines including BVDV 1a and 2a strains, does not protect against BVDV $1 \mathrm{~b}$ strain (21). Additionally, antigenic variations between BVDV 1a and 1c have shown to be similar to that seen among BVDV 1a and $1 \mathrm{~b}$ strain, which had also been proven (22). Viral diversity is an important feature to consider when designing diagnostic tools, efficient surveillance protocols, and vaccines for BVD control programs. Phylogenetic analysis is a useful tool for identifying the endemic subgenotypes in a population, dissemination to other regions, and emerging or reintroducing new BVDV variants.

\section{BVDV IN MEXICO}

The beef and dairy cattle industries comprise the major avenues of animal-derived protein production in Mexico, representing $43 \%$ of the total livestock production ${ }^{1}$ These national industries include 35 million animals ${ }^{2}$ According to the Ministry of environment and natural resources (SEMARNAT), in Mexico, there are over 1.1 million livestock production units such as stables, farms, ranches, dairies, and feedlots with a wide heterogeneity in herds size, management, and socialeconomic situation. The states with the largest number of units are Veracruz, Chiapas, Oaxaca, and Guerrero $(23,24)$. Production systems vary from traditional backyard farms to highly specialized, high-input systems with cattle management classified as extensive, semi extensive, and intensive $(25,26)$. Beef and dairy farms are distributed throughout the national territory. In 2019, the entities with a higher population of animals destined for beef production were Veracruz, Jalisco, Chiapas, Chihuahua, and Michoacan; while Jalisco, Durango, Chihuahua, Coahuila, and Guanajuato were described as the states that concentrate the major animal inventory for dairies at national level (27). The annual beef and milk production reported is about 2 million $\mathrm{t}^{3}$ and around 12275 million L, respectively (28). Mexico is ranked among the 10 major producers in worldwide bovine meat and milk $(29,30)$.

Official information and scientific reports regarding BVD in Mexico are limited; hence, the present review attempts to describe and discuss an overview of BVD current situation in Mexico using available data. BVD is considered an endemic disease with a nationwide distribution listed by the Secretary of Agriculture and Rural Development (SADER). The stance of the Mexican government is that "BVD infections are of minor risk since they can be controlled by good livestock practices and monthly mandatory notifications to the National System of Epidemiological Surveillance (SIVE)" (31). Because BVD is categorized as a non-regulated disease in Mexico no control or eradication programs have been implemented. Control and prevention activities are no mandatory; therefore, nonofficial or partial control programs are based only in voluntary procedures. Systematic vaccine application is considered an essential prevention tool; however, no vaccination coverage is known hitherto. Biosafety measures and monitoring are applied depending on the BVD knowledge that cattle producers and handlers have. Hence, prevention and control strategies are

\footnotetext{
${ }^{1}$ http://www.campomexicano.gob.mx/boletinsiap/019e.html\#: :text=El \%20centro\%20del\%20pa\%C3\%ADs\%20genera,para\%20el\%20ganado\%20en $\% 20$ pie (accessed May 15, 2021).

${ }^{2}$ https://www.gob.mx/siap/documentos/poblacion-ganadera-136762 (accessed May 15, 2021).

${ }^{3}$ https://www.gob.mx/agricultura/prensa/la-produccion-de-carne-de-res-enmexico-mantiene-un-crecimiento-anual-sostenible-del-2-5-agricultura\#:\$sim\$: text $=$ De\%20acuerdo\%20con\%20el\%20panorama,en\%2061.6\%20millones\%20de $\% 20$ toneladas (accessed May 15, 2021).
} 
diverse among farms. In addition, due to underreporting, the assessment of BVD status of individuals animals or herds has not been possible. SIVE data of BVDV of 2015, 2016, 2017, 2018, 2020 and a preliminary till may, 2021 is available. A total of 5,705 cases were reported $(868,1,182,944,868,1,118$, and 283 cases, respectively) in bovines from several states, with no description in wildlife. Annual reports to the World Organization Animal Health (OIE) describes the National Center of Diagnosis Services in Animal Health (CENAPA) as a reference laboratory in charge of BVD diagnosis. Assays implemented for BVDV detection include viral isolation, qRT-PCR, ELISA, and viral neutralization; description of surveillance, monitoring, and border precaution as prevention and control actions are also described (32). Nevertheless, although prevention and mitigation activities are applied, there are insufficient official reports, and incomplete information regarding BVDV subgenotypes and biotypes distribution; accordingly, national BVDV genetic diversity remains unknown. Declaring BVD as a disease of slight risk could be associated with the scant information available regarding BVD incidence and the prevalence of persistently infected animals in beef and dairy herds. To date, there is no national or regional estimation of economic losses related to BVD, no surveys that establish a national BVD epidemiological status, and no available reports of BVDV vaccination coverage in cattle.

Conversely, the neighboring countries, the United States and Canada, have implemented testing strategies for BVDV diagnosis, genetic characterization, seroprevalence, and PI detection; therefore, BVDV epidemiology is better understood (33-35). Further, significant losses due to BVDV infection in beef and dairy cattle have been reported $(36,37)$. Implemented voluntary control activities are applied (33); however, no mandatory systematic BVD prevention, control, and eradication programs have been implemented in these countries $(33,38)$.

Because there is no requirement to report BVD cases in Mexico and no centralized national clearing house for diagnostic and epidemiological data, BVD is probably underdiagnosed in Mexico. The typing of viral variant and their distribution in specific geographic regions, incidence, and prevalence are yet to be determined. Moreover, no financial and economic surveys are conducted currently; consequently, no comparisons of the economic impact due to BVDV infections and benefits from the control activities are reported.

National BVD prevention and control have depended primarily on vaccination with no national coordination, using modified live (MLV) and inactivated virus vaccines licensed for Mexican cattle producers. BVDV vaccines are formulated with reference strains from the US (NADL, Singer, Oregon C24V, 296c, NY-1, and New York-93), including both biotypes with diverse combinations of these, together with other bovine viruses like Bovine parainfluenza-3 virus, Bovine herpesvirus type 1 and Bovine respiratory syncytial virus; however, no vaccination register information is officially recorded.

In most cases, the purpose of vaccination is to prevent reproductive failure, gastrointestinal disorders, and respiratory disease; therefore, it is common to include BVDV1 and sometimes BVDV2 in multi-component vaccines, i.e., vaccines against BRDC. When applied improperly, unwanted effects need to be considered and evaluated; i.e., the use of MLV's of CP strains during pregnancy had led to reproductive disorders, recombination with field strains, and development of mucosal disease in PI animals (39-41). These events are rarely identified and reported in the Mexican cattle industry. Moreover, BVDV strains used in vaccines have not been tested for efficacy against Mexican field isolates; thus, further studies regarding the protection conferred in livestock will need to be done.

\section{BVDV Seroprevalence and Genetic Diversity}

Initially, the evaluation of BVDV infections in Mexico was performed by detecting antibodies against BVDV in several herds (Table 1). Thus, the first study of BVD in Mexico was based on detecting BVDV neutralizing antibodies in 47 nonvaccinated animals with a clinical history of abortions, infertility, and respiratory signs reported seropositivity of 75\% (20).

Subsequently, a study by Suzan et al., described a $70.5 \%$ seroprevalence in dairy cattle from two states and $62.5 \%$ in beef cattle from 10 states (42) as serologic evidence of BVDV infection in healthy cattle. Similar results were achieved in assays of vaccinated animals belonging to farms with a record of reproductive failures associated with coinfections with pathogens like Leptospira, Brucella, Neospora, and infectious bovine rhinotracheitis virus (IBR). Even though vaccination can play a role in the prevalence detected, the antibody titer significantly increased in animals that have aborted should be considered $(45,49)$.

Previous studies in unvaccinated animals calculate a seroprevalence among $74-81.27 \%(47,48,53)$. Hence, the elevated level of seropositivity in these surveys indicates recent infection or the presence of a PI animal among the population surveyed (54). Further, moderate exposure levels demonstrated in evaluations in healthy animals (seropositivity of $47.8-54.6 \%$ ) reveal an old BVDV exposition or an early acute infection $(50,52,53)$. Similarly, studies in non-vaccinated animals with a record of abortion and miscarriage showed a seroprevalence ranging from 46.6 to $60.35 \%(46,50)$. However, in these studies, the role of BVDV in reproductive disorders is not fully understood due to the detection of other reproductive pathogens involved and non-BVDV isolation or antigen detection performed in the aborted fetuses. Lower antibody response was detected in a southeast state, where the $14 \%$ seroprevalence reflected a natural exposure to BVDV (43).

In addition, contact between livestock and other domestic animal and wildlife species can explain these species' seroprevalence rates. For example, previous surveys in Mexico detected a 20\% BVDV seropositivity in domestic goats (42). Moreover, in a population of white-tail deer, an average seroprevalence of $63.53 \%$ was detected. Factors involved in the high prevalence estimated in this study were cattle management, the prevalence of BVD in cattle in neighboring areas, and continuous grazing practices. Likewise, ranches with the highest antibody prevalence were those with cattle cohabitation 
TABLE 1 | Seroprevalence studies performed in cattle from Mexico.

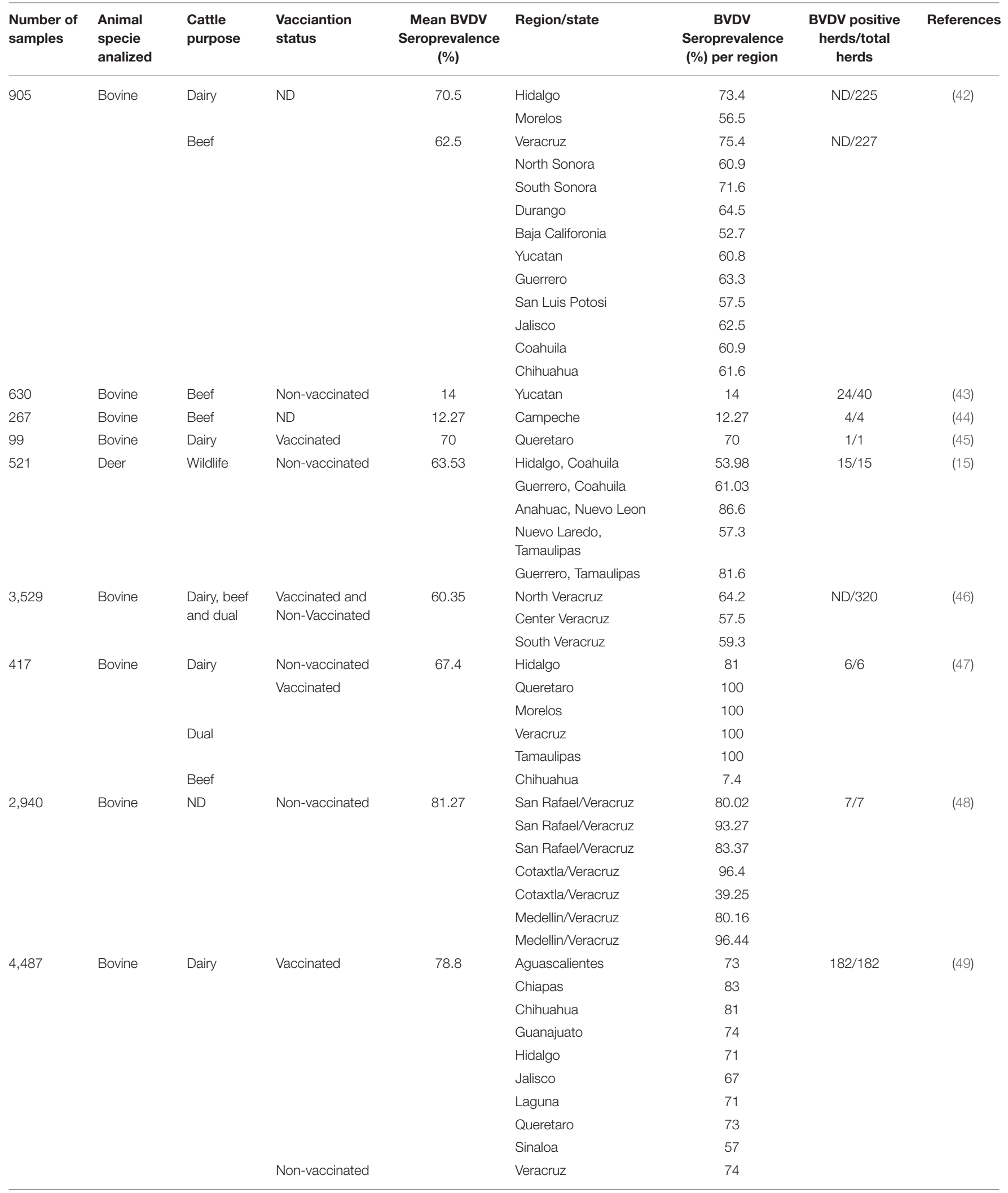


TABLE 1 | Continued

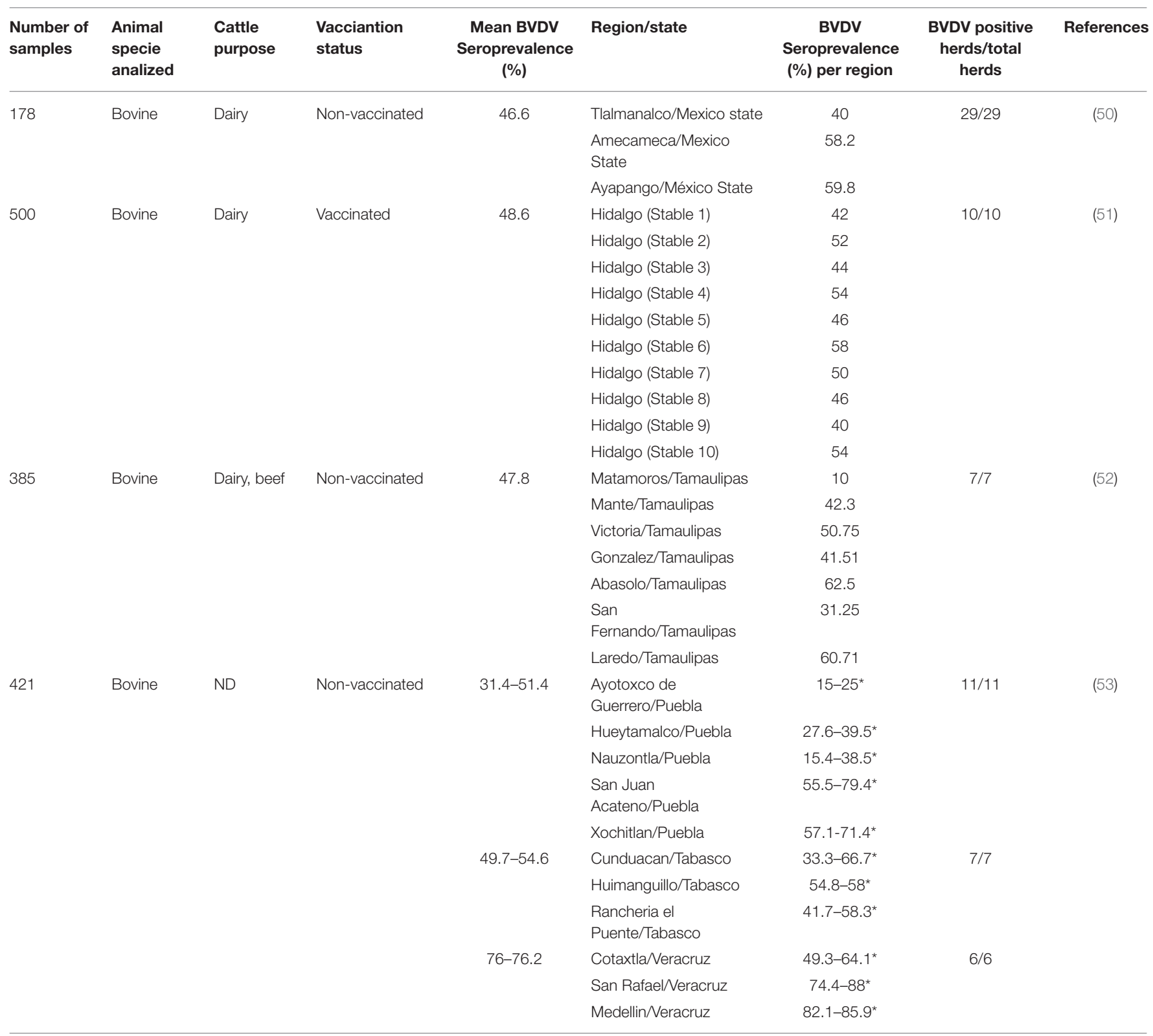

ND: No data.

*Values represent a two-times period of BVDV seroprevalence evaluation from the same animal population.

compared to ranches with no cattle (15). Epidemiological data support that BVDV can be maintained in white-tail deer and capable of shedding BVDV consistent to PI cattle. Therefore, deer are considered an important BVDV source when sufficient contacts between PI deer and naïve cattle occur (55).

The serological results show that a substantial proportion of Mexican cattle has been exposed to BVDV, whether by natural exposure or vaccination; these are important criteria to consider for diagnosis purposes. However, after immunization, the BVDV antibodies titer detected results from the application of vaccines and did not reflect the natural, historical exposition of cattle to BVDV field strains. Thus, identification of antibody response requires an accurate assessment to avoid seroprevalence misinterpretation. Moreover, antibody response in seronegative immunotolerant animals should also be considered as PI cattle can respond only to heterologous BVDV strains other than the specific strain that induces immunotolerance (56). In addition, based on national seroprevalence studies, variations in antibody prevalence among locations within the same state and region were commonly reported. These variations may be due to differences in management practices such as addition of untested cattle and mixing of cattle from different sources in large herds $(57,58)$. 
Little information is available regarding the genetic diversity of BVDV in cattle populations from Mexico. A recent study examining viruses found in cattle from six Mexican states detected four subgenotypes: BVDV-1a, 1b, 1c, BVDV-2a, and no evidence of HoBi-like viruses were reported (19). In this study, BVDV-1c was the most frequently detected subgenotype followed by $1 \mathrm{~b}, 1 \mathrm{a}$, and $2 \mathrm{a}$, representing a unique prevalence pattern of BVDV subgenotypes reported in North America. In comparison, BVDV-1a, $1 \mathrm{~b}$, and $2 \mathrm{a}$ are the subgenotypes predominantly detected in cattle from the US and Canada, while BVDV-1c subgenotype has not been detected (22). In addition, BVDV subgenotype $1 \mathrm{~b}$ was detected in healthy water buffaloes and isolated from a captive fallow deer from Mexican wildlife (59). Moreover, the detection of the pestivirus border disease virus (BDV) genotype 1 has been described in clinically healthy cattle from Mexico (60), reinforcing the fact that close contact between animal species is a risk factors for interspecies transfer. The latter has important implications in BVD control because other ruminant pestiviruses can cause misinterpretations in BVDV tests, as many tests used to

\section{REFERENCES}

1. Brodersen BW. Bovine viral diarrhea virus infections: manifestations of infection and recent advances in understanding pathogenesis and control. Vet Pathol. (2014) 51:453-64. doi: 10.1177/0300985813520250

2. Smith DB, Meyers G, Bukh J, Gould EA, Monath T, Muerhoff AS. Proposed revision to the taxonomy of the genus Pestivirus, family Flaviviridae. J Gen Virol. (2017) 98:2106-12. doi: 10.1099/jgv.0.000873

3. Yesilbag K, Alpay G, Becher P. Variability and global distribution of subgenotypes of bovine viral diarrhea virus. Viruses. (2017) 9:128. doi: $10.3390 /$ v9060128

4. Ridpath JF. Bovine viral diarrhea virus: global status. Vet Clin North Am Food Anim Pract. (2010) 26:105-21. doi: 10.1016/j.cvfa.2009.10.007

5. Becher P, Orlich M, Shannon AD, Horner G, Konig M, Thiel HJ. Phylogenetic analysis of pestiviruses from domestic and wild ruminants. J Gen Virol. (1997) 78:1357e66. doi: 10.1099/0022-1317-78-6-1357

6. Vilcek S, Paton D, Lowings P, Björklund H, Nettleton P, Belák S. Genetic analysis of pestiviruses at the 3' end of the genome. Virus Genes. (1999) 18:107-14. doi: 10.1023/A:1008000231604

7. Neill J. Molecular biology of bovine viral diarrhea virus. Biologicals. (2013) 41:2-7. doi: 10.1016/j.biologicals.2012.07.002

8. Liebler-Tenorio E. Pathogenesis. In: Goyal SM, Ridpath JF, editors. Bovine Viral Diarrhea Virus: Diagnosis, Management and Control. Ames, IA: Blackwell publishing (2006) 893.

9. Fulton RW, Purdy CW, Confer AW, Saliki JT, Loan RW, Briggs RE, et al. Bovine viral diarrhea viral infections in feeder calves with respiratory disease: interactions with Pasteurella spp., parainfluenza-3 virus, and bovine respiratory syncytial virus. Can J Vet Res. (2000) 64:151-9.

10. Chase CC, Elmowalid G, Yousif AA. The immune response to bovine viral diarrhea virus: a constantly changing picture. Vet Clin North Am Food Anim Pract. (2004) 20:95-114. doi: 10.1016/j.cvfa.2003.11.004

11. Brodersen BW, Kelling CL. Effect of concurrent experimentally induced bovine respiratory syncytial virus and bovine viral diarrhea virus infection on respiratory tract and enteric diseases in calves. Am J Vet Res. (1998) 59:1423-30.

12. Lamm CG, Broaddus CC, Holyoak GR. Distribution of bovine viral diarrhea virus antigen in aborted fetal and neonatal goats by immunohistochemistry. Vet Pathol. (2009) 46:54-8. doi: 10.1354/vp.46-1-54

13. Kulcsar G, Soos P, Kucsera L, Glávits R, Pálfi V. Pathogenicity of a bovine viral diarrhoea virus strain in pregnant sows: short communication. Acta Vet Hung. (2001) 49:117-20. doi: 10.1556/004.49.2001.1.14 detect BVDV do not differentiate among BVDV and BDV infections (61).

Surveillance and monitoring of BVDV variants circulating in the Mexican cattle population are crucial for establishing national/regional epidemiological status and to better understand BVDV ecology in Mexico. The information yielded would contribute to the development of efficacious control strategies specific to Mexico.

\section{AUTHOR CONTRIBUTIONS}

NG-R: writing-original draft and writing-review \& editing. FJB-A and AV-R: review \& editing. JR: writing, review, conceptualization, and editing \& funding acquisition. All authors contributed to the article and approved the submitted version.

\section{FUNDING}

Funding for this review was provided by the USDA/ARS National Animal Disease Center.

14. Carman S, Carr N, DeLay J, Baxi M, Deregt D, Hazlett M. Bovine viral diarrhea virus in alpaca: abortion and persistent infection. J Vet Diagn Invest. (2005) 6:589-93. doi: 10.1177/104063870501700613

15. Cantu A, Ortega-S JA, Mosqueda J, Garcia-Vazquez Z, Henke SE, George JE. Prevalence of infectious agents in free-ranging whitetailed deer in northeastern Mexico. J Wildl Dis. (2008) 44:1002-7. doi: 10.7589/0090-3558-44.4.1002

16. Silveira S, Weber MN, Mósena AC, da Silva MS, Streck AF, Pescador CA, et al. Genetic diversity of Brazilian bovine pestiviruses detected between 1995 and 2014. Transbound Emerg Dis. (2017) 64:613-23. doi: 10.1111/tbed.12427

17. Decaro N, Lucente MS, Mari V, Cirone F, Cordioli P, Camero M, et al. Atypical pestivirus and severe respiratory disease in Calves, Europe. Emerg Infect Dis. (2011) 17:1549-52. doi: 10.3201/eid1708.101447

18. Bauermann FV, Flores EF, Falkenberg SM, Weiblen R, Ridpath JF. Lack of evidence for the presence of emerging HoBi-like viruses in North American fetal bovine serum lots. J Vet Diagn Invest. (2014) 26:10-7. doi: 10.1177/1040638713518208

19. Gómez-Romero N, Basurto-Alcántara FJ, Verdugo-Rodríguez A, Bauermann FV, Ridpath JF. Genetic diversity of bovine viral diarrhea virus in cattle from Mexico. J Vet Diagn Invest. (2017) 29:362-5. doi: 10.1177/10406387176 90187

20. Correa-Giron P, Brown LN, Bryner JH. Presencia de anticuerpos contra rinotraqueitis infecciosa, diarrhea viral bovina, parainfluenza 3, brucellosis, leptospirosis, vibriosis y Haemophilus somnus en sueros de bovinos con problemas patológicos reproductores y respiratorios. Tec Pecu Mex. (1975) 29:26-33.

21. Fulton RW, Briggs RE, Ridpath JF, Saliki JT, Confer AW, Payton ME, et al. Transmission of bovine viral diarrhea virus $1 \mathrm{~b}$ to susceptible and vaccinated calves by exposure to persistently infected calves. Can J Vet Res. (2005) 69:161-9. Available online at: https://scholar.google.com/scholar lookup?hl=es-419\&volume $=29 \&$ publication_year $=1975 \&$ pages $=26-33 \&$ author=P+Correa-Gir\%C3\%B3n\&title $=$ Presencia + de + anticuerpos + contra + rinotraqueitis+infecciosa $\% 2 \mathrm{C}+$ diarrea+viral+bovina $\% 2 \mathrm{C}+$ parainfluenza+ $3 \% 2 \mathrm{C}+$ brucelosis $\% 2 \mathrm{C}+$ leptospirosis $\% 2 \mathrm{C}+$ vibriosis $+\mathrm{y}+$ Haemophilus+ somnus+en+sueros+de+bovinos+con+problemas+patol\%C3\%B3gicos+ reproductores+y+respiratorios

22. Ridpath JF, Fulton RW, Kirkland PD, Neill JD. Prevalence and antigenic differences observed between Bovine viral diarrhea virus subgenotypes isolated from cattle in Australia and feedlots in the southwestern United States. J Vet Diagn Invest. (2010) 22:184-91. doi: $10.1177 / 104063871002200203$ 
23. SEMARNAT. Secretaría de Medio Ambiente y Recursos Naturales. Consulta temática. Unidades de producción y existencias de ganado bovino según sistema de producción, 2007. (Revisión, Octubre 2020). Available online at: http://dgeiawf.semarnat.gob.mx:8080/ibi_apps/WFServlet?IBIF_ex= D2_AGRIGAN01_15andIBIC_user=dgeia_mceandIBIC_pass=dgeia_ mceandNOMBREENTIDAD $=\wedge$ ।ast (accessed May 31, 2021).

24. Leos-Rodrígez JA, Serrano PA, Salas GJM, Ramírez MPP, Sagarnaga VM. Caracterización de ganaderos y unidades de producción pecuaria beneficiarios del programa de estímulos a la productividad ganadera (PROGAN) en México, DF. Agric Soc Des. (2008) 2:213-30. Available online at: http://www.scielo.org.mx/scielo.php?script=sci_arttext\&pid=S1870$54722008000200005 \& \operatorname{lng}=\mathrm{es} \& \mathrm{nrm}=\mathrm{iso}$

25. Rivas L, Holmann F. Sistemas de doble propósito y su viabilidad en el contexto de los pequeños y medianos productores en América Latina Tropical. In: Curso Internacional de Actualización en el Manejo de Ganado Bovino de Doble Propósito. Veracruz, México, November. (2002). p. 1-38.

26. Rojo-Rubio R, Vázquez-Armijo JF, Pérez-Hernández P, MendozaMartínez GD, Salem AZM, Albarrán-Portillo B, et al. Dual purpose cattle production in Mexico. Trop Anim Health Prod. (2009) 41:715-21. doi: $10.1007 /$ s11250-008-9249-8

27. SIAP. Servicio de información agroalimentaria y pesquera. Población ganadera. Inventario 2019 bovino para carne/Inventario 2019 bovino para leche. Available online at: https://www.gob.mx/siap/documentos/poblacionganadera-136762 (accessed July 11, 2021).

28. SADER. Secretaría de agricultura y desarrollo rural (SADER). Servicio de información agroalimentaria y pesquera. Boletín de leche cuarto trimestre. (Octubre-Diciembre 2019). Available online at: http://infosiap.siap.gob.mx/ opt/boletlech/Bolet\%C3\%ADn\%20de\%20Leche\%20enero-marzo\%202019. pdf (accessed May 15, 2021).

29. United States Department of Agriculture. Foreign Agricultural Service. Dairy: World Markets and Trade. Dairy production and Trade Develpments. (2020). Available online at: https://apps.fas.usda.gov/psdonline/circulars/dairy.pdf (accessed May 16, 2021).

30. United States Department of Agriculture. Foreign Agricultural Service. Livestock and Poultry: World Markets and Trade. (2021). Available online at: https://apps.fas.usda.gov/psdonline/circulars/livestock_poultry.pdf (accessed May 16, 2021).

31. SEGOB. Secretaría de Gobernación. Diario oficial de la nación. Acuerdo mediante el cual se dan a conocer en los Estados Unidos Mexicanos la enfermedades y plagas exóticas y endémicas de notificación obligatoria de los animales terrestres y acuáticos. Available online at: https://dof.gob.mx/nota_ detalle.php? codigo=5545304andfecha=29/11/2018 (accessed May 17, 2021).

32. SIVE. Sistema Nacional de Vigilancia Epidemiológica. Informes de situación Zoosanitaria Nacional: 2012-2012. (2021). Available online at: https://www. gob.mx/senasica/acciones-y-programas/sistema-nacional-de-vigilanciaepidemiologica- sive (accessed June 3, 2021).

33. Van Campen H. Epidemiology control of BVD in the U.S. Vet Microbiol. (2010) 142:94-8. doi: 10.1016/j.vetmic.2009.09.049

34. Chernick A, van der Meer F. Evolution of Bovine viral diarrhea virus in Canada from 1997 to 2013. Virology. (2017) 509:232-8. doi: 10.1016/j.virol.2017.06.024

35. Waldner CL, Campbell JR. Use of serologic evaluation for antibodies against bovine viral diarrhea virus for detection of persistently infected calves in beef herds. Am J Vet Res. (2005) 66:825-34. doi: 10.2460/ajvr.2005.66.825

36. Chi J, VanLeeuwen JA, Weersink A, Keefe GP. Direct production losses and treatment costs from bovine viral diarrhoea virus, bovine leukosis virus, Mycobacterium avium subspecies paratuberculosis, Neospora caninum. Prev Vet Med. (2002) 55:137-53. doi: 10.1016/S0167-5877(02)00094-6

37. Carman S, van Dreumel T, Ridpath J, Hazlett M, Alves D, Dubovi E, et al. Severe acute bovine viral diarrhea in Ontario, 1993-1995. J Vet Diagn Invest. (1998) 10:27-35. doi: 10.1177/104063879801000106

38. Scharnböck B, Roch FF, Richter V, Funke C, Firth CL, Obritzhauser $\mathrm{W}$, et al. A meta-analysis of bovine viral diarrhoea virus (BVDV) prevalences in the global cattle population. Sci Rep. (2018) 8:14420. doi: 10.1038/s41598-018-32831-2

39. Orban S, Liess B, Hafez SM, Frey HR, Blindow H, Sasse-Patzer B. Studies on transplacental transmissibility of a Bovine Virus Diarrhoea (BVD) vaccine virus. I. Inoculation of pregnant cows 15 to 90 days before parturition. (190th to 265th day of gestation). Zentralbl Veterinarmed B. (1983) 30:619-34. doi: 10.1111/j.1439-0450.1983.tb01888.x

40. Liess B, Orban S, Frey HR, Trautwein G, Wiefel W, Blindow H. Studies on transplacental transmissibility of a bovine virus diarrhoea (BVD) vaccine virus in cattle. II. Inoculation of pregnant cows without detectable neutralizing antibodies to BVD virus 90-229 days before parturition (51st to 190th day of gestation). Zentralbl Veterinarmed B. (1984) 31:669-81. doi: 10.1111/j.1439-0450.1984.tb01350.x

41. Fritzemeier J, Haas L, Liebler E, Moennig V, Greiser-Wilke I. The development of early vs. late onset mucosal disease is a consequence of two different pathogenic mechanisms. Arch Virol. (1997) 142:1335-50. doi: 10.1007/s007050050164

42. Suzan VM, Onuma M, Aguilar RE, Murakami Y. Prevalence of bovine herpesvirus-1, parainfluenza-3, bovine rotavirus, bovine viral diarrhea, bovine adenovirus-7, bovine leukemia virus and bluetongue virus antibodies in cattle in Mexico. Jpn J Vet Res. (1983) 31:125-32.

43. Solis-Calderon JJ, Segura-Correa VM, Segura-Correa JC. Bovine viral diarrhoea virus in beef cattle herds of Yucatan, Mexico: seroprevalence and risk factors. Prev Vet Med. (2005) 72:253-62. doi: 10.1016/j.prevetmed.2005.06.004

44. Cordova-Izquierdo A, Córdova-Jiménez CA, Córdova-Jiménez MS, SaltijeralOaxaca JA, Ruiz-Lang CG, Xolalpa-Campos VM, et al. Seroprevalence of cattle abortive diseases from Mexican humid tropic. Rev Vet. (2007) 2:139-42.

45. Escamilla HP, Martínez MJJ, Medina CM, Morales SE. Frequency and causes of infectious abortion in a dairy herd in Queretaro, Mexico. Can J Vet Res. (2007) 71:314-7.

46. Romero-Salas D. Folleto Técnico No. 1 Enfermedades que causan abortos en la ganadería bovina. Universidad Veracruzana. Facultad de Medicina Veterinaria y Zootecnia. Región Veracruz (2012). p. 44. Available online at: https://www.uv.mx/personal/dromero/files/2013/05/FolletoTecnicoNo.1DoraRomeroSalas2012.pdf (accession April 04, 2021).

47. Gómez-Romero N. Determinación de los genotipos del virus de la diarrea viral bovina predominantes en poblaciones ganaderas de 6 regiones de México. [Dissertation/master's thesis] [México City CDMX]: Universidad Nacional Autónoma de México-Facultad de Medicina Veterinaria y Zootecnia (2016).

48. Abad-Zavaleta J, Ríos-Utrera A, Rosete-Fernández JV, García-Camacho A, Zárate-Martínez JP. Prevalencia de rinotraqueítis infecciosa bovina y diarrea viral bovina en hembras en tres épocas del año en la Zona Centro de Veracruz. Nova scientia [revista en la Internet]. (2016) 8:213-27. doi: $10.21640 /$ ns.v8i16.433

49. Milian-Suazo F, Hernández-Ortíz R, Hernández-Andrade L, Alvarado-Islas A, Díaz-Aparicio E, Mejía-Estrada F, et al. Seroprevalence and risk factors for reproductive diseases in dairy cattle in Mexico. J Vet Med Anim Health. (2016) 8:89-98. doi: 10.5897/JVMAH2016.0483

50. Ojeda-Carrasco JJ, Espinosa-Ayala E, Hernández-García PA, Rojas-Martínez C, Álvarez-Martínez JA. Seroprevalencia de enfermedades que afectan la reproducción de bovinos para leche con énfasis en neosporosis. Ecosistemas y recur. Agropecuarios. (2016) 3:243-9. Available online at: http://www.scielo. org.mx/scielo.php?script=sci_arttext\&pid=S2007-90282016000200243\&lng= es\&nrm=iso

51. Sánchez-Castilleja YM, Rodríguez Diego JG, Pedroso M, Cuello S. Simultaneidad serológica de Neospora caninum con Brucella abortus y los virus de la rinotraqueítis infecciosa bovina y diarrea viral bovina en bovinos pertenecientes al Estado de Hidalgo, México. Rev Salud Anim. (2012) 34:95-100. Available online at: http://scielo.sld.cu/scielo.php?script= sci_arttext\&pid=S0253-570X2012000200006\&lng=es\&nrm=iso

52. Segura-Correa JC, Zapata-Campos CC, Jasso-Obregón JO, Martinez-Burnes J, López-Zavala R. Seroprevalence and risk factors associated with bovine herpesvirus 1 and bovine viral diarrhea virus in North-Eastern Mexico. Open Vet J. (2016) 6:143-9. doi: 10.4314/ovj.v6i2.12

53. Rosete Fernández JV, Ríos UA, Zárate Martínez JP, Olazarán JS, Granados Zurita L, Fragoso Islas A, et al. Prevalencia de anticuerpos contra diarrea viral bovina en vacas no vacunadas en los estados de Puebla, Tabasco y Veracruz, México. Rev Mex Cienc. (2018) 9:555-66. doi: 10.22319/rmcp.v9 i3.4599

54. Brownlie J, Thompson I, Curwen A. Bovine virus diarrhoea virus strategic decisions for diagnosis and control. Practice. (2000) 22:176-87. doi: 10.1136/inpract.22.4.176 
55. Passler T, Ditchkoff SS, Walz PH. Bovine Viral Diarrhea Virus (BVDV) in White-Tailed Deer (Odocoileus virginianus). Front Microbiol. (2016) 7:945. doi: 10.3389 /fmicb.2016.00945

56. Fulton RW, Step DL, Ridpath JF, Saliki JT, Confer AW, Johnson BJ, et al. Response of calves persistently infected with noncytopathic bovine viral diarrhea virus (BVDV) subtype $1 \mathrm{~b}$ after vaccination with heterologous BVDV strains in modified live virus vaccines and Mannheimia haemolytica bacterintoxoid. Vaccine. (2003) 21:2980-5. doi: 10.1016/S0264-410X(03)00118-X

57. Orjuela J, Navarrete M, Betancourt A, Roqueme L, Cortez E, Morrison RB. Salud y productividad en bovinos de la costa norte de Colombia. World Anim Rev. (1991) 69:7-14.

58. Mainar-Jaime RC, Berzal-Herranz B, Arias P, Rojo-Vazquez FA. Epidemiological pattern and risk factors associated with bovine viraldiarrhoea (BVDV) infection in a non-vaccinated dairy-cattle population from the Asturias region of Spain. Prev Vet Med. (2001) 52:63-73. doi: 10.1016/S0167-5877(01)00239-2

59. Medina-Gudiño J. Detección y genotipificación de pestivirus en ungulados de fauna silvestre en cautiverio en Mexico. [Dissertation/master's thesis] [México City CDMX]: Universidad Nacional Autónoma de México-Facultad de Medicina Veterinaria y Zootecnia (2020).

60. Gómez-Romero N, Basurto-Alcántara FJ, Verdugo-Rodríguez A, LagunesQuintanilla R, Bauermann FV, Ridpath JF. Detection of border disease virus in Mexican cattle. Transbound Emerg Dis. (2018) 65:267-71. doi: $10.1111 /$ tbed. 12641
61. Strong R, La Rocca SA, Ibata G, Sandvik T. Antigenic and genetic characterisation of border disease viruses isolated from UK cattle. Vet Microbiol. (2010) 141:208-15. doi: 10.1016/j.vetmic.2009.09.010

Conflict of Interest: JR was employed by Ridpath Consulting, LLC.

The remaining authors declare that the research was conducted in the absence of any commercial or financial relationships that could be construed as a potential conflict of interest.

Publisher's Note: All claims expressed in this article are solely those of the authors and do not necessarily represent those of their affiliated organizations, or those of the publisher, the editors and the reviewers. Any product that may be evaluated in this article, or claim that may be made by its manufacturer, is not guaranteed or endorsed by the publisher.

Copyright (ㅇ 2021 Gomez-Romero, Ridpath, Basurto-Alcantara and VerdugoRodriguez. This is an open-access article distributed under the terms of the Creative Commons Attribution License (CC BY). The use, distribution or reproduction in other forums is permitted, provided the original author(s) and the copyright owner(s) are credited and that the original publication in this journal is cited, in accordance with accepted academic practice. No use, distribution or reproduction is permitted which does not comply with these terms. 